\title{
Assessment of Ground Water Quality: Selected Villages of Mahabubnagar Mandal \& District, Telangana State (India)
}

\author{
Dasaiah Srinivasulu ${ }^{1}$, Eshwar Chandra ${ }^{2}$, Sateesh Kumar ${ }^{3}$, Rahul $^{4}$, Santhosh $^{5}$, Gayathri ${ }^{6}$ \\ ${ }^{1}$ Assistant Professor \& In Charge, Environmental Engineering Lab, Department of Environmental Studies, Jaya Prakash Narayan College of \\ Engineering, Mahabubnagar, Telangana-509 001 \\ 2,3,4,5, ${ }^{6}$ B.Tech Students, Department of Civil Engineering, Jaya Prakash Narayan College of Engineering, Mahabubnagar, Telangana-509
} 001.

\begin{abstract}
Present study aimed to analyse and compare the ground water quality with WHO standards of selected villages of Mahabubnagar mandal. Ground water samples collected where ground water is the only source for drinking. All the ground water samples were subjected to analysis of physico chemical parameters such as colour, turbidity, total dissolved solids, pH, electrical conductivity, chlorides, total hardness, nitrates, fluoride, sulphates etc. The obtained results compared with WHO standards. Findings reveal that ground water quality of the villages were deteriorating, most of the parameters found excess in limit. Almost all ground water samples in study area found unfit for drinking purpose. It is suggesting that the evaluation of water quality parameters as well as water quality management practices should be carried out periodically to protect water resources. The awareness campaign of waterborne diseases and importance of safe water for human health should be commenced by Rural Water Supply and Sanitation (RWS) department.
\end{abstract}

Keywords: Ground water, turbidity, pH, Electrical Conductivity, Hardness, dissolved solids

\section{Introduction}

Three fourth of the earth surface covered by water resources. Water is very important to life. Water quality is critical factor affecting human health and welfare. Studies showed that approximately 1.7 million deaths and 1.9 million disabilities worldwide are attributable to unsafe water, poor sanitation and hygiene. The problem is backward socio economic development resulting in one of lowest standard of living, poor environmental conditions and low level of social services.

Ground water is an important resource for domestic and agriculture in both rural and urban areas of India. The chemical composition of ground water is very important criteria that determine the quality of water. Water quality is very important and often degraded due to agriculture, industrial and human activities. Even though the natural environmental processes provide by means of removing pollutants from water, there are definite limits. It is upto the people to provide security to protect and maintain the quality of water. Drinking water with good quality is very important to improve the life of people and prevent form diseases.

Pollution of ground water comes from many sources such as discharge of waste, pesticide residues from agriculture, industries and municipalities are the main sources. Sometimes surface runoff also brings mud, leaves and human and animal wastes into surface water bodies. The pollutants may enter directly into the ground water and contaminating it.

\subsection{Study Area}

Mahabub nagar is the first largest district in Telangana state interms of area(18432 sq.km) covered. It is also also known as Palamoor. Mahabubnagar district head quarters town named after Mir Mahabub Alikhan, the Nizam of Hyderabad. It extends from north latitude $77^{0} 55^{\prime} 00^{\prime \prime}$ and $17^{0}$ 20 ' $00^{\prime \prime}$ and east longitude $77^{\circ} 15^{\prime} 00^{\prime \prime}$ and covered in the survey of India topographical maps no. $56 \mathrm{G}$ and $56 \mathrm{~K}$. The area of the district having four revenue divisions, 64 mandals and 1554 revenue villages.

In this area, the natural resources availability is very high but facing very difficulty with water resources due to less rainfall and high evaporation rate. Even though water resources very less in quantity, due to lack of awareness in farmer community available present water bodies are also under contamination. Hence the present study has been under taken to determine the physico chemical characteristics of ground water in selected villages of Mahabubnagar mandal where the ground water is the main source for drinking.

\section{Materials and Methods}

The sampling places are referred as stations and coded as S1 to $\mathrm{S} 15$. The stations are represented as Ramreddy gudem (S1), Bokkalonipally(S2), Zamisthapur(S3), Telugu gudem(S4), Oblaipally(S5), Machenpally(S6), Nehru Nagar(S7), Ramchandra puram(S8), Chowder pally(S9), Appai pally(S10), Narsapur(S11) Dharmapur(S12), Alipur(S13), Kodur(S14) and Oblaipally Thanda(S15) which are comes under Mahabubnagar mandal. Water sample were collected from various bore wells of respective villages. The samples were collected in $1000 \mathrm{ml}$ plastic bottles which were 


\section{International Journal of Science and Research (IJSR) \\ ISSN (Online): 2319-7064 \\ Index Copernicus Value (2013): 6.14 | Impact Factor (2015): 6.391}

previously washed drenched overnight with $5 \%$ of $\mathrm{HNO}_{3}$ solution to avoid contamination. During sampling extra care was taken and plastic bottles were rinsed several times with the water being collected. All the samples were found odourless and colourless. After sampling onsite analysis was done for Temperature, $\mathrm{pH}$, Electrical Conductivity due to their unsteadiness in nature. Samples were then transferred to Environmental Engineering lab, Jaya Prakash Narayan College of Engineering, Dharmapur, Mahabubnagar and kept at $8^{0} \mathrm{C}-10^{\circ} \mathrm{C}$ in refrigerator prior the time of analysis.

\section{Results and Discussion}

Table 1: Physico chemical analysis results of ground water samples of Mahabubnagar mandal

\begin{tabular}{|c|c|c|c|c|c|c|c|c|c|}
\hline Name of the Village & $\mathrm{pH}$ & $\mathrm{EC}$ & $\mathrm{TDS}$ & $\mathrm{TA}$ & $\mathrm{TH}$ & $\mathrm{F}$ & $\mathrm{Cl}$ & $\mathrm{NO}_{3}$ & $\mathrm{So}_{4}$ \\
\hline Ram reddy gudem(S1) & 7.09 & 1802 & 955 & 552 & 416 & 1.65 & 348 & 19 & 111 \\
\hline Bokkaloni pally(S2) & 7.11 & 1644 & 871 & 552 & 412 & 1.57 & 388 & 24 & 66 \\
\hline Zamistapur(S3) & 8.19 & 1641 & 869 & 576 & 360 & 1.91 & 328 & 17 & 59 \\
\hline Telugu gudem(S4) & 7.68 & 1412 & 748 & 356 & 268 & 1.34 & 236 & 26 & 52 \\
\hline Oblaipally(S5) & 7.78 & 1515 & 802 & 384 & 236 & 1.63 & 308 & 17 & 41 \\
\hline Machen pally(S6) & 7.59 & 2710 & 1436 & 432 & 712 & 1.12 & 672 & 109 & 112 \\
\hline Nehru nagar(S7) & 7.2 & 612 & 324 & 264 & 164 & 1.16 & 92 & 40 & 18 \\
\hline Ram chandra puram(S8) & 7.82 & 709 & 375 & 172 & 152 & 1.24 & 52 & 27 & 17 \\
\hline Chowder pally(S9) & 7.12 & 1216 & 644 & 544 & 318 & 1.37 & 240 & 26 & 38 \\
\hline Appaipally(S10) & 7.89 & 1788 & 947 & 584 & 348 & 1.16 & 360 & 26 & 57 \\
\hline Narsapur(S11) & 7.35 & 1180 & 625 & 188 & 136 & 1.81 & 92 & 6 & 99 \\
\hline Dharmapur(S12) & 7.14 & 1574 & 834 & 596 & 412 & 1.62 & 428 & 864 & 64 \\
\hline Alipur(S13) & 7.19 & 2760 & 1462 & 516 & 700 & 1.6 & 668 & 132 & 122 \\
\hline Kodur(S14) & 7.8 & 1775 & 937 & 576 & 332 & 1.13 & 302 & 24 & 54 \\
\hline Oblaipally Thanda(S15) & 7.8 & 1672 & 816 & 390 & 243 & 1.7 & 315 & 21 & 48 \\
\hline
\end{tabular}

All parameters are expressed in $\mathrm{mg} / \mathrm{lit}$. except $\mathrm{pH}$ and EC. EC in $\mu \mathrm{S} / \mathrm{cm}$.

\section{1. $\mathrm{pH}$ of water}

The $\mathrm{pH}$ of water is refers to the measure of hydrogen ions concentration in water. It ranges from 0 to 14 . In general, water with a $\mathrm{pH}$ of 7 is considered neutral while lower of it referred acidic and a $\mathrm{pH}$ greater than 7 known as basic. Normally, water $\mathrm{pH}$ ranges from 6 to 8.5. It is noticed that water with low $\mathrm{pH}$ is tend to be toxic and with high degree of $\mathrm{pH}$ it is turned into bitter taste. According to WHO standards $\mathrm{pH}$ of water should be 6.5 to 8.5 . In this study samples were found 7.09 to 8.19 which are slight basic. The highest $\mathrm{pH}$ value 8.19 observed at Zamistha pur station (S3) where as the lowest value i.e 7.09 found at Ram reddy gudem (S1). All the ground water samples were found within the limits as prescribed by WHO.

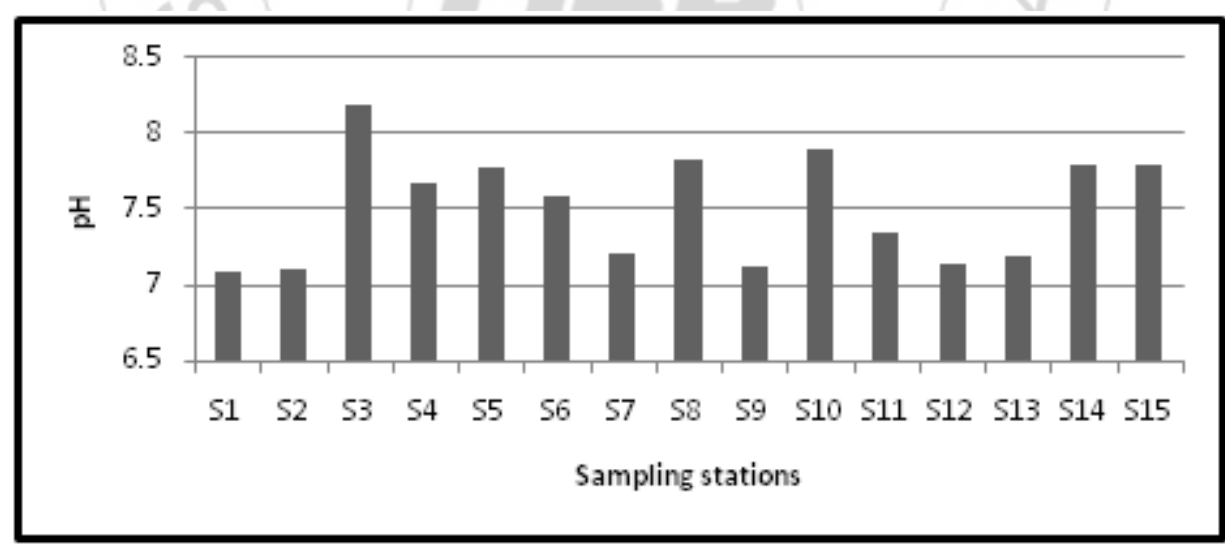

Figure 1: pH values of ground water samples in study area

\subsection{Electrical Conductivity (EC)}

Pure water is not a good conductor of electric current rather a good insulator. Increase in ions concentration enhances the electrical conductivity of water. Generally, the amount of dissolved solids in water determines the electrical conductivity. Electrical conductivity (EC) is actually measures the ionic process of a solution that enables it to transmit current. According to WHO standards EC value should not exceeded $400 \mu \mathrm{S} / \mathrm{cm}$. In study area all the ground water samples were found excess values of electrical conductivity. The value ranges from $612 \mu \mathrm{S} / \mathrm{cm}$ to 2760 $\mu \mathrm{S} / \mathrm{cm}$. The highest EC found at Alipur (S13) i.e 2760 $\mu \mathrm{S} / \mathrm{cm}$. 


\section{International Journal of Science and Research (IJSR)}

ISSN (Online): 2319-7064

Index Copernicus Value (2013): 6.14 | Impact Factor (2015): 6.391

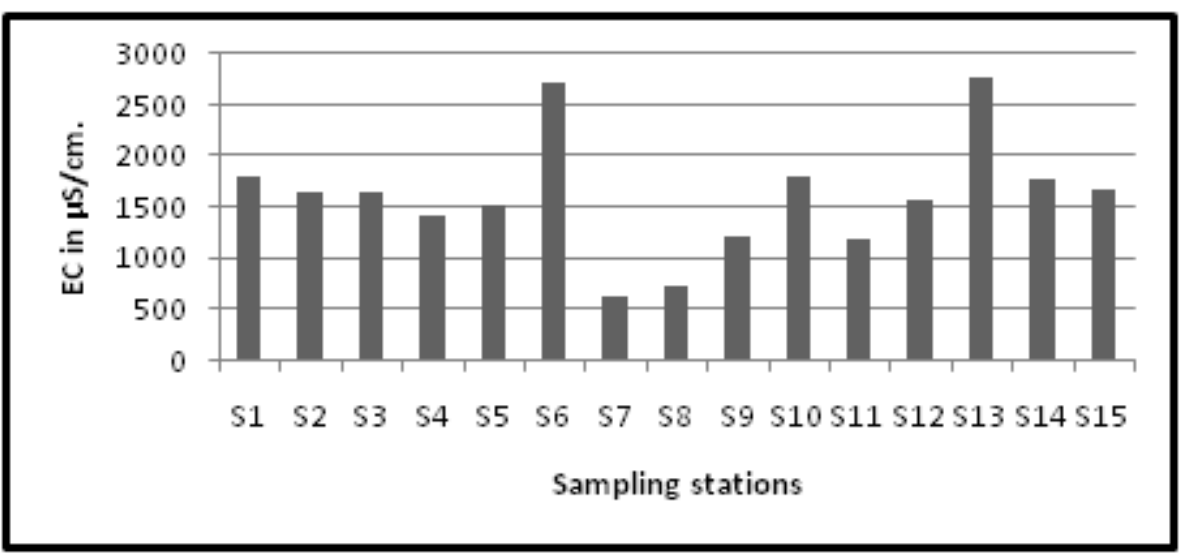

Figure 2: Electrical conductivity values of ground water samples in study area.

\subsection{Total Dissolved Solids (TDS)}

Water has the ability to dissolve a wide range of inorganic and some organic minerals or salts such as potassium, calcium, sodium, bicarbonates, chlorides, magnesium, sulphates etc. These minerals produced un-wanted taste and diluted colour in appearance of water. There is no agreement have been developed on negative or positive effects of water that exceeds.The WHO standard limit of 1,000 ppm. Total dissolved solids (TDS) in drinking water is originates many ways from sewage to urban industrial wastewater etc. Therefore, TDS test is considered a sign to determine the general quality of the water. The values of ground water samples vary between $324 \mathrm{ppm}$. to $1462 \mathrm{ppm}$. Ground water samples of Machen pally(S6) and Alipur(S13) found 1436 $\mathrm{ppm}$. and $1462 \mathrm{ppm}$. of TDS respectively and which were found excess in limits as prescribed by WHO. Remaining all samples found within the prescribed limit.

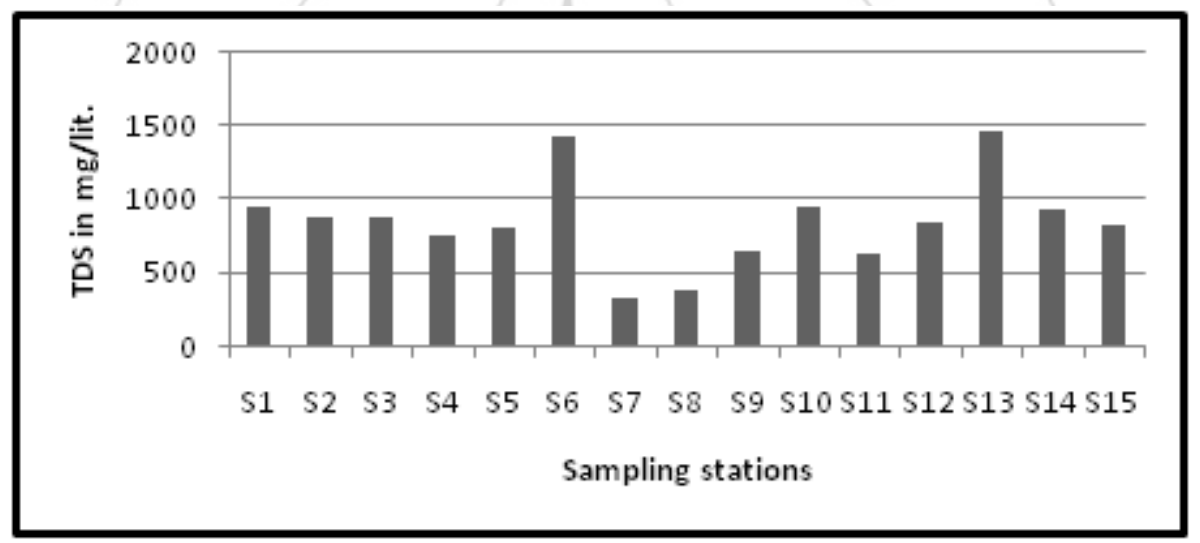

Figure 3: TDS values of ground water samples in study area.

\subsection{Total Alkalinity (TA)}

Alkalinity is the presence of one or more ions in water including hydroxides, carbonates and bicarbonates. It can be defined as the capacity to neutralize acid. Moderate concentration of alkalinity is desirable in most water supplies to stable the corrosive effects of acidity. However, excessive quantities may cause a number of problems. The
WHO standards tell the alkalinity only in terms of total dissolved solids (TDS) of $500 \mathrm{mg} / \mathrm{l}$. In study areas, results show that alkalinity ranges from $172 \mathrm{mg} / \mathrm{lit}$ to $596 \mathrm{mg} / \mathrm{lit} .53 \%$ of ground water samples were found excess in limits among highest TA found at Dharmapur station (S12) i.e 596mg/lit. 


\section{International Journal of Science and Research (IJSR) \\ ISSN (Online): 2319-7064}

Index Copernicus Value (2013): 6.14 | Impact Factor (2015): 6.391

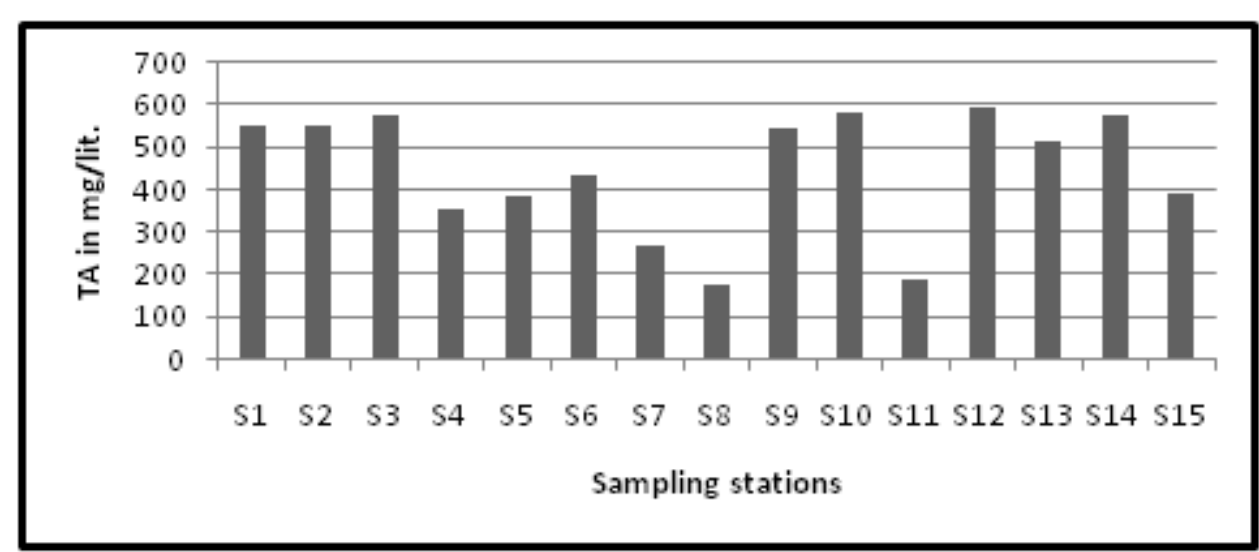

Figure 4: Total Alkalinity values of ground water samples in study area

\subsection{Total Hardness (TH)}

Hard water is characterized with high mineral contents that are usually not harmful for humans. It is often measured as calcium carbonate $(\mathrm{CaCO} 3)$ because it consist mainly calcium, magnesium and their salts such as carbonates, bicarbonates, sulphates and chlorides are the most dissolved ions in hard water. According to World Health Organization
(WHO) hardness of water should be $500 \mathrm{mg} / \mathrm{l}$. In study areas, hardness ranges from $136 \mathrm{mg} / \mathrm{lit}$. to $712 \mathrm{mg} / \mathrm{lit}$. Among 15 stations two Stations were found excess permissible limits namely Machen pally(712mg/lit.) and Alipur(700mg/lit).

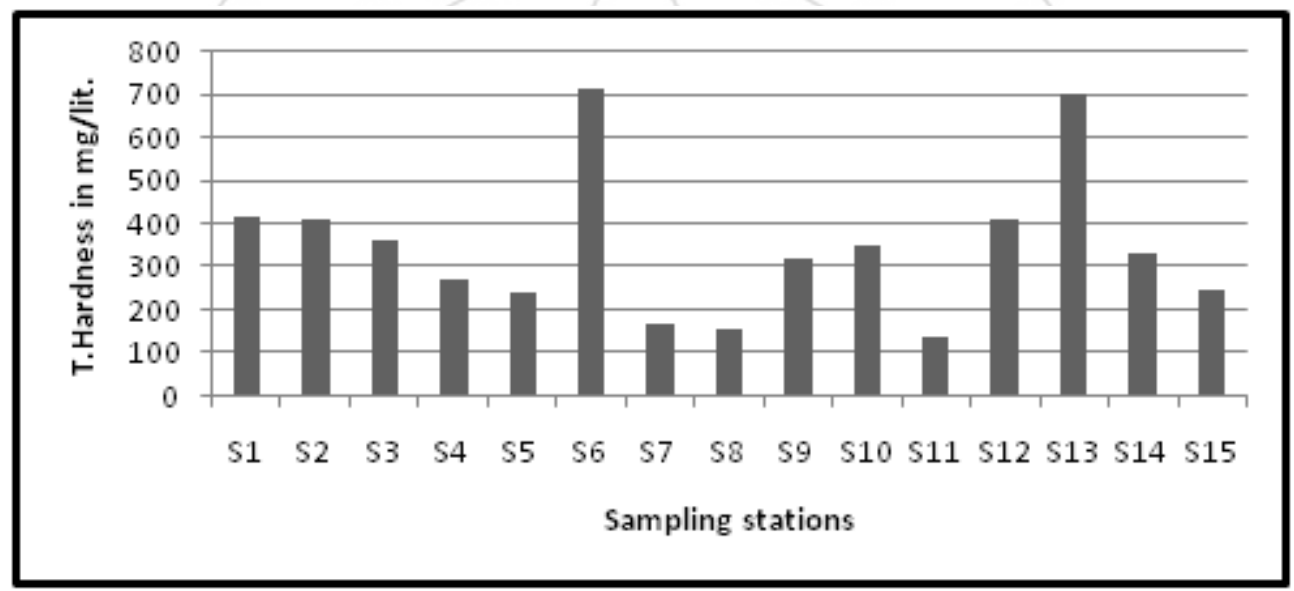

Figure 5: Total Hardness values of ground water samples in study area.

\subsection{Fluorides (F)}

Fluorides may be presence due to breakdown of rocks and soils or infiltration of chemical fertilizers from agriculture land. The maximum allowed limit of fluoride according to WHO is $1.0 \mathrm{mg} / \mathrm{lit}$. All the ground water samples found excess in limits. The high concentration of fluoride in the study area poses a sign of water quality problem. The highest fluoride value $(1.91 \mathrm{mg} / \mathrm{lit}$.) recorded in Zamistapur (S3)station ground water sample.

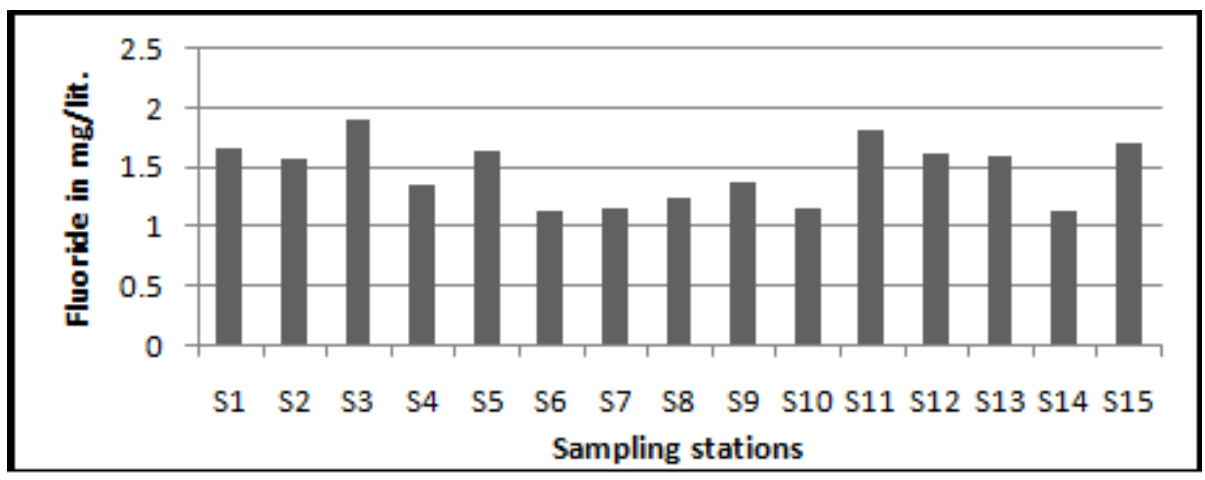

Figure 6: Fluoride values of ground water samples in study area. 


\section{International Journal of Science and Research (IJSR) \\ ISSN (Online): 2319-7064}

Index Copernicus Value (2013): 6.14 | Impact Factor (2015): 6.391

\subsection{Chloride (Cl)}

Chloride is mainly obtained from the dissolution of salts of hydrochloric acid as table salt $(\mathrm{NaCl})$, sodium carbonate added through industrial waste, sewage, sea water etc. Surface water bodies often have low concentration of chlorides as compare to ground water. It has key importance for metabolism activity in human body and other main physiological processes. According to WHO standards concentration of chloride should not exceed $250 \mathrm{mg} / \mathrm{l}$. In study areas, results clear that the concentration of Chloride ranges from $52 \mathrm{mg} / \mathrm{lit}$ to $672 \mathrm{mg} / \mathrm{lit}$. $66 \%$ samples were found excess in limits as prescribed by WHO.

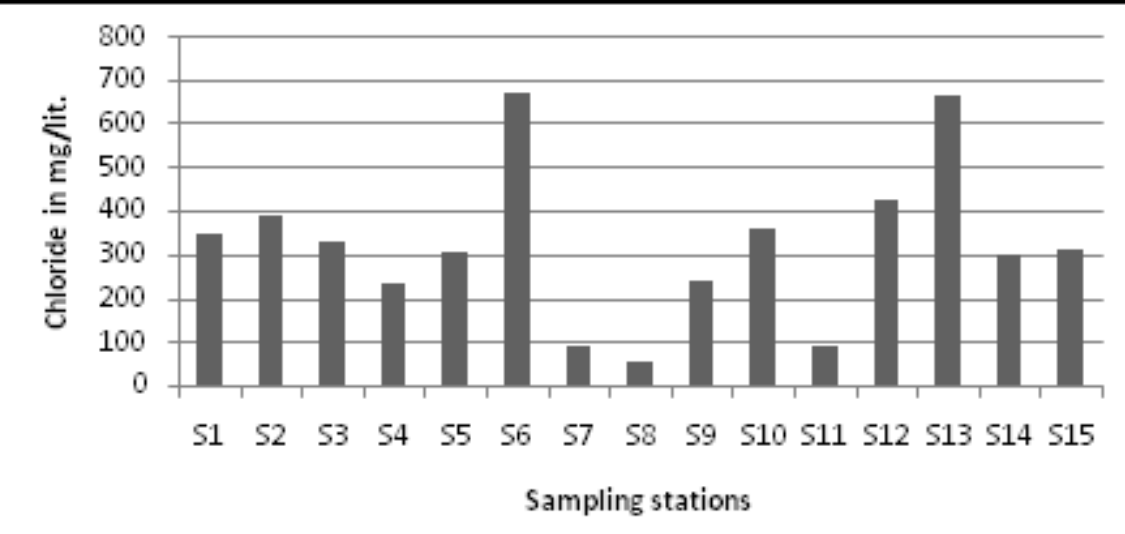

Figure 7: Chloride values of ground water samples in study area.

\subsection{Nitrate (NO3):}

Nitrate one of the most important diseases causing parameters of water quality particularly blue baby syndrome in infants. The sources of nitrate are nitrogen cycle, industrial waste, nitrogenous fertilizers etc. The WHO allows maximum permissible limit of nitrate in drinking water is $10 \mathrm{mg} / \mathrm{l}$. In study areas, results clear that the concentration of nitrate ranges from $6 \mathrm{mg} / \mathrm{lit}$. to $132 \mathrm{mg} / \mathrm{lit}$. Except Alipur(S13 found $132 \mathrm{mg} / \mathrm{lit})$ and Machen pally(S6 found $109 \mathrm{mg} / \mathrm{lit}$ ) remaining all samples were found within the limits as prescribed by WHO.

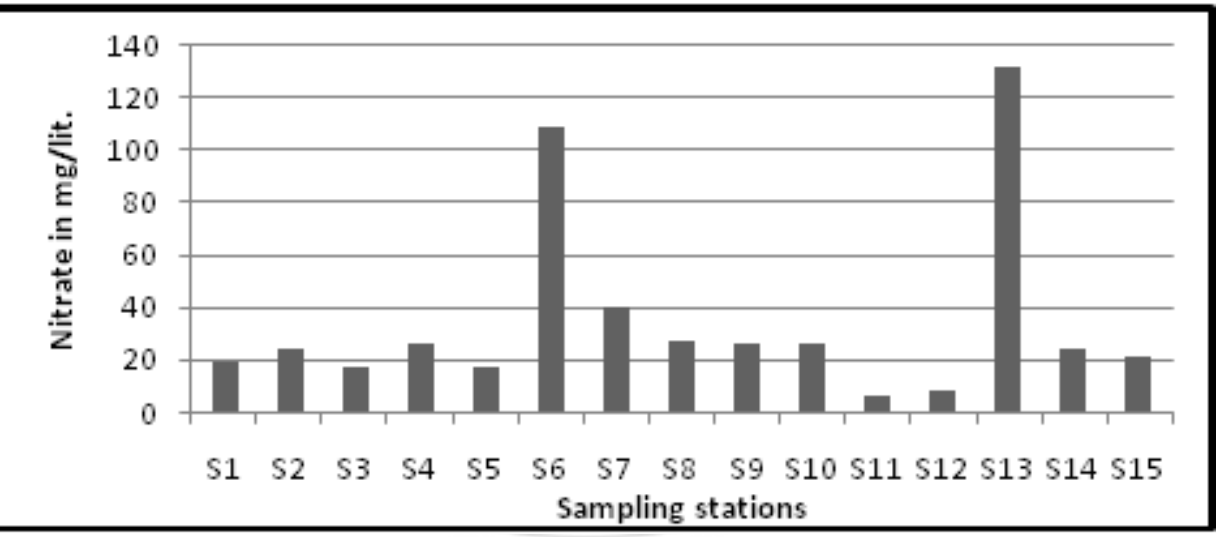

Figure 8: Nitrate values of ground water samples in study area

\subsection{Sulphate (SO4)}

Sulphate mainly derived from the dissolution of salts of sulphuric acid and abundantly found in almost all water bodies. High concentration of sulphate may be due to oxidation of pyrite and mine drainage etc. The WHO has established $250 \mathrm{mg} / \mathrm{l}$ as the highest desirable limit of sulphate in drinking water. In study areas, concentration of sulphate ranges from $17 \mathrm{mg} / \mathrm{lit}$. to $122 \mathrm{mg} / \mathrm{lit}$. All the samples were found within the limits. 


\section{International Journal of Science and Research (IJSR) \\ ISSN (Online): 2319-7064}

Index Copernicus Value (2013): 6.14 | Impact Factor (2015): 6.391

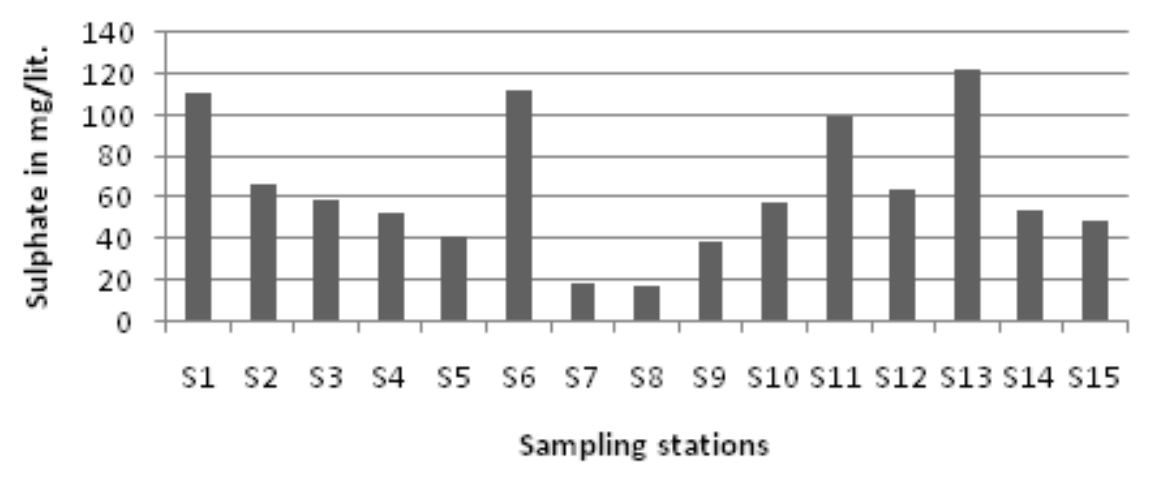

Figure 9: Sulphate values of ground water samples in study area

\section{Conclusion}

After physico chemical analysis of 15 ground water samples of Mahabubnagar mandal, the analysis values of different parameters were found excess in limits indicating poor water quality which are unfit for drinking and may effect on human health. In order to rescue precious human lives from water related diseases current study suggests that regular monitoring of ground water quality should be practiced. Concerned government should installed more water purification plants to provide safe drinking water. Sewer drains should kept away from water supply drains to avoid waste water leaching in ground water. Sanitary conditions should be improved on urgent basis. The awareness campaign of waterborne diseases and importance of safe water for human health should be commenced by Rural Water Supply and Sanitation (RWS) department.

\section{Acknowledgement}

The author would like to show gratitude the chairman Sri K S Ravi Kumar Sir, Jaya Prakash Narayan College of Engineering, Dharmapur, Mahabubnagar for providing the lab facility and constant support during this work.

\section{References}

[1] Abdo, M. H., 2005. Physicochemicalcharacteristics of Abu Za baal ponds, Egypt. Egyptial Journal of Aquatic Research, 31(2) : 1 - 15.

[2] Anilakumary KS, Abdul Aziz PK, Natrajan P., (2007), Water quality of the Adimalathma estuary southwest coast of India, Journal of Marine biological association of India, 49, pp 1-6.

[3] APHA (2005), Standard methods for the examination of water and waste water. 21st Edn., Washington, D. C.

[4] anerjea S. M., (1967), Water quality and soil condition of fishponds in states of India in relation to fish production, Indian journal of Fisheries, 14(1\&2), pp 115-144.

[5] Dasaiah Srinivasulu and GRK Naidu., Drinking Water Quality of Some Selected Villages of Manopad Mandal, Mahabubnagar District, Telangana State (India) International Journal of Civil and Structural Engineering Research Vol. 3, Issue 2, pp: (133-140), Month: October 2015 - March 2016
[6] Dasaiah Srinivasulu and GRK Naidu., Assessment of Fluoride and Nitrate in Ground Water: Selected Villages of Mahabubnagar Mandal \& District, Telangana State (India) International Journal of Science and Research (IJSR) Volume 5 Issue 3, March 2016. pp: 1709-1701.

[7] Egereonu, U.U and D. Emezium, 2006. Physicochemical analysis of selected ground water in River State, Nigeria, to ascertain pollution level, encrustation and corrosion potential, J. Chem. Soc. Nigeria, 31(1 \& 2): 141-146.

[8] Guru Prasad, B., 2003. Evaluation of Water Quality in Tadepalli Mandal of Guntur Dist. A.P.; Nature Environ. Poll. Tech., 2(3): 273-276.

[9] Karanth, K.R (1987): Groundwater Assessment Development and Management Tata McGraw Hill publishing company Ltd., New Delhi, 725p.

[10] Krishnamurthy R.(1990): Hydro-biological studies of Wohar reservoir Aurangabad (Maharashtra State) India. J. Environ. Biol. 11(3), 335-343.

[11] Kumaraswamy, N., 1991. Physico-chemical analysis of ground water in pravara area, Dist. Ahmednagar, Maharashtra, Poll. Res., 10: 13. 1991.

[12] Malik, M. A., Azam, M., \& Saboor, A. (2010). Water Quality Status of Upper KPK and Northern Areas of Pakistan. Pakistan Council of Research in Water Resources (PCRWR), Water Resources Research Centre, Peshawar, Pakistan.

[13] Meenakshi, V.K.Garg, Kavita, Renuka and Anju malik,2004.Ground water quality of some villages of Haryana,India: focus on fluoride and fluorosis.Jour.Hazard.Mater,106B: pp 85-97

[14] Memon, M., Soomro, M. S., Akhtar, M. S., \& Memon, K. S. (2011). Drinking Water Quality Assessment in Southern Sindh (Pakistan). Environmental Monitoring and Assessment, 177, 39-50.

[15] Patil, V. T. and Patil, R. R. (2010): Physico chemical analysis of selected ground water samples of Amalner town in Jalgaon district, Maharashtra, India. E - J. of Chemistry, 7: pp $111-116$.

[16] Patil P.N., Sawant D.V. and Deshmukh R.N., PhysicoChemical Parameters for testing of water- A review, International Journal of Environmental Sciences, 3(3), 1194-1207 (2012)

[17] Rajagopal, T., A. Thangamani and G. Archunan, 2010. Comparison of physicochemical parameters and phytoplankton species diversity of two perennial ponds in Sattur area, Tamilnadu. J. Environ. Biol., 31(5) : 784 $-794$. 


\section{International Journal of Science and Research (IJSR) \\ ISSN (Online): 2319-7064}

Index Copernicus Value (2013): 6.14 | Impact Factor (2015): 6.391

[18] Rao, N. S. 2006. Seasonal variation of groundwater quality in a part of Guntur District, Andhra Pradesh, India. Environmental Geology. 49, 413-429.

[19] S. A. Makwana, C. G. Patel and T. J. Patel, PhysicoChemical analysis of drinking water of Gandhinagar District Arch. Appl. Sci. Res., 4 (1), 2012, 461-464.

[20] Venkatachalam M.R. and Jebanesan. A., 1998. Correlation among water quality parameters for Groundwater in Chidambaram town. Indian Journal of Environmental Protection. 18(10): 734- 738.

[21] W. H. O. (2009) Guidelines for drinking water quality Vol1. Recommendations. World Health Organization, Geneva. pp 130.

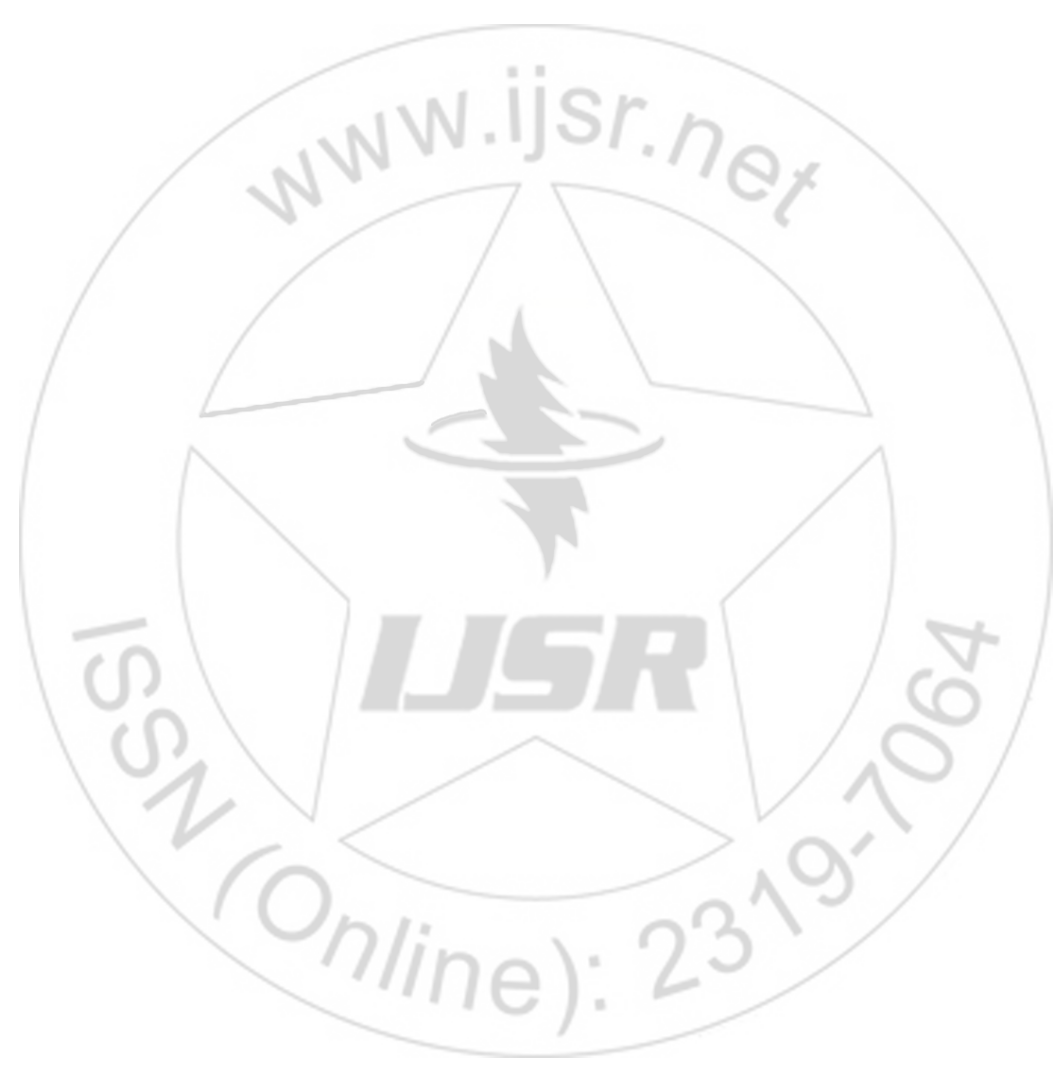

Volume 5 Issue 5, May 2016 